\title{
Jarosław Korpysa*
}

\section{Using case study \\ for tertiary education in the field of economics}

\section{Introduction}

A case study is a popular method adopted by academic teachers and an effective instrument for sharing their knowledge and experience with students. It enables not only to observe particular stages of a single process taking place in a given organization, but also to understand analogical or similar processes occurring in other market entities [4]. Furthermore, case studies allows both students and teachers to think critically and analytically. It has a profound effect on their creativity, effectiveness in noticing market opportunities and threats to their solutions, as well as motivation to accomplish their goals. It shows them how to present and defend their ideas, enables them to acquire confidence in their abilities and skills, develop their ability to take decisions and help them integrate theoretical and practical knowledge.

Keeping in mind the above characteristics, it is relevant to analyse ways in which the case study method is used for tertiary education in the field of economics. The problem will be verified on the basis of results of a questionnaire survey addressed to students of economics and related fields of study

\section{Case study vs. the educational process}

Literature on the subject distinguishes a number of practical uses of case studies as a tool supporting the didactic process. Królikowska mentions the following stages in employing case studies for educational purposes:

- establishing a diagnosis based on a problem suggested by the teacher or chosen by students themselves;

\footnotetext{
* The Faculty of Economics and Management of the University of Szczecin, Department of Microeconomics
} 
- seeking solutions in line with the already established criteria for solving the problem;

- discussing possible solutions in order to enable students not only to present their opinions on feasible solutions to the problem, but also to take a common position;

- transferring conclusions into a real-life situation thanks to which students may verify the usefulness of knowledge acquired during classes and confront it with real problems arising from resource management [4].

A completely different approach is held by Werd who proposes the following stages in using case studies as a teaching method:

- identifying the problem;

- defining the aim of the case study;

- formulating the question, thesis or hypothesis;

- answering the question posed or verifying the thesis/hypothesis;

- determining the data collection method;

- determining the time devoted to the case study;

- defining the sources of information useful for getting to know issues under consideration;

- collecting data;

- analysing data and drawing conclusions to be used in further studies [8]. Another useful approach is held by Labov. He is inclined to believe that case studies for educational purposes should include the following stages:

- summary of a problem - should illustrate the problem described by means of a given case;

- focus on the problem - one should answer the following questions: who? (who is dealing with the problem), when? (moment in time when the problem is being faced), what? (description of the root of the problem), where? (place of the problem occurrence);

- consequences following from the problem - one should describe the consequences following from the problem under study;

- assessment - one should perform a synthetic analysis of the effect that the problem has on environment;

- final result - presenting solution to the problem;

- conclusion - verification of problem solutions based on the analysis in stages no 3 and 4 [5].

Having in mind the aforementioned methodological remarks, it seems reasonable and universal to adopt the model proposed by Greenhalg, which is shown in Figure 1. Subsequently, the model will be supplemented by practical remarks made by the author of the present paper. 


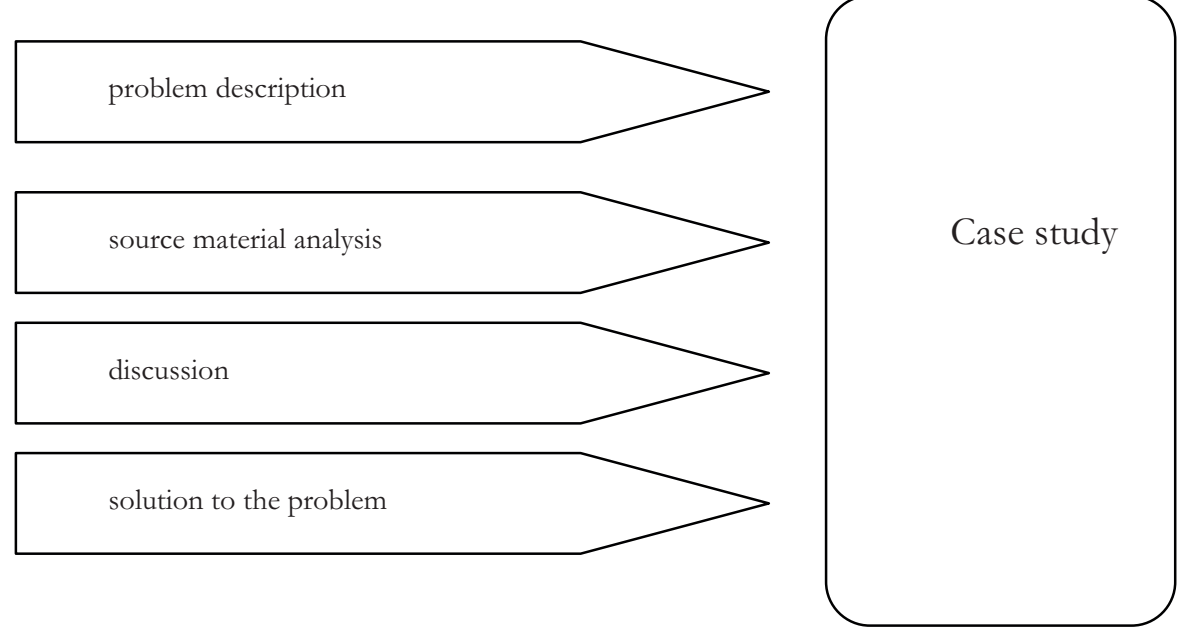

Figure 1. Model presenting the implementation of case studies for educational purposes Source: own elaboration based on [1, pp. 181-194]

The above model consists of four stages. The first stage, i.e. description of the problem, involves a comprehensive analysis of the issue under discussion. Here attention should be paid to the fact that while describing the problem, it is crucial to use plain and understandable language. In case of using specialist terminology, a glossary of terms should be included at the end of case study. Furthermore, the problem under analysis ought to refer to a real-life situation which, in turn, finds reflection in the curriculum followed during classes. In fact, only understandable problems that bear resemblance to reality may interest students and make them involved in creative solution-seeking. As a result, goals set by the teacher can be accomplished. At this stage of the study, a pedagogue ought to select a thematic area to which the problem will refer and organize (if possible) meeting between students and specialists, i.e. people experienced in certain area. Such a meeting is to prepare students for solving a given problem. If it is not possible for both groups to meet, the teacher should make use of practical materials, namely reports, articles, TV programmes and radio broadcasts. Furthermore, it is essential for the material to be relevant and appropriate to the essence and form of a given case.

The second stage involves the analysis of source material. The verification of material may consist in reading the excerpt of case study description or watching relevant audio-visual recordings. The teacher's main objectives are as follows: creating an atmosphere favourable to reading or watching film material, 
answering every question asked by students, and determining the span of time during which they should get to know the material presented.

The third stage is a discussion held between students and the teacher. It is aimed mainly at exchanging their views on the case. What is of major importance here is the way in which the teacher leads the discussion.

To be more specific, three types of discussion can be distinguished, namely group discussion, subgroup discussion and face-to-face discussion:

- Group discussion - once a given case has been introduced, discussion is held and moderated by the teacher in order to select an optimum solution. At this stage, it is extremely useful to write down opinions expressed by discussion participants (i.e. students), e.g. on a blackboard, flipchart, etc. This is aimed at presenting both students and the teacher with possible alternatives. Furthermore, such a discussion enables its participants to avoid repeating possible solutions. Everyone is free to present their ideas and thus has a chance to be appreciated. Last but not least, group discussion facilitates the selection of optimum solution through eliminating the least effective alternatives.

- Subgroup discussion - involves dividing the group into subgroups whose members confront their views and eventually adopt a common position. Subsequently, the group leader presents the remaining groups with conclusions that his/her group has drawn. Just as in the case of group discussion, it is helpful if the teacher (moderator) or leaders of particular groups write down opinions expressed by each group, e.g. on a blackboard, flipchart, etc. Once all the views have been presented, discussion is held again by the entire group of students and moderated by the teacher in order to select optimum solution.

- Face-to-face discussion - this form enables discussion participants to share their views with another person (as the name suggests - it is held between two people). Subsequently, the teacher moderates the exchange of views among all the students [2].

The teacher performs a fundamental role in the discussion. He/she encourages students to voice their opinions.

The last stage of the process entails problem solving. In the course of analysis and discussion, the group should select the optimum solution. Depending on the issues under consideration, several alternatives may be agreed upon. Nonetheless, numerous studies $[6 ; 7 ; 3]$ have confirmed that choosing one solution is the most effective from the perspective of didactic process. Therefore, the teacher ought to summarize all the opinions expressed by the discussion participants, establish (together with the group) criteria for selecting certain solutions and discuss the strengths and weaknesses of particular alternatives in order to eliminate the least valuable solutions.

Bearing the above in mind, it is relevant to analyse the effect of the case study method on tertiary education in the field of economics. 


\section{The results of questionnaire survey}

In order to accomplish the main goal of the present paper, questionnaire survey was conducted and addressed to students of economics and related fields at the University of Szczecin. The survey was undertaken as part of the project entitled "Using case study method for improving the quality and effectiveness of tertiary education in the field of economics" carried out in the framework of Scientific cooperation between Eastern Europe and Switzerland (SCOPES). The main tool was a structuralised questionnaire addressed to 150 students. All in all, 134 correctly filled in questionnaires were returned. The survey was carried out between November 2011 and January 2012.

As far as the characteristic of respondents is concerned, it should be stated that female students represented $57 \%$ of survey participants, whereas male students constituted $43 \%$. The majority (84\%) attended first cycle studies (BSc), while $14 \%$ of those surveyed attended second cycle studies (MSc). With reference to the fields of study, most respondents studied finance and banking (35\%) as well as management (30\%). On the contrary, the lowest percentage of those surveyed studied economics (16\%) as well as information science and econometrics (9\%).

Once the criteria for population division are known, the subject matter may be analysed comprehensively. To begin with, the respondents were asked to enumerate teaching methods adopted by academic teachers during lectures and classes.

Figure 2 below presents detailed results.

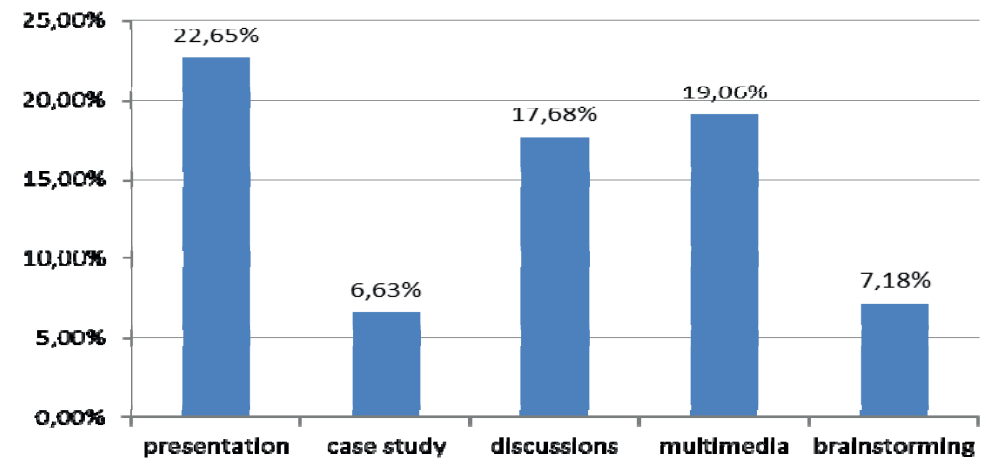

Figure 2. Presents methods employed during lectures Source: own elaboration based on the questionnaire survey

According to the respondents, the most popular teaching method employed during lectures was power point presentation (22.65\%). Other options selected by considerably high percentage of students were multimedia (19.06\%) and discus- 
sions (17.68\%). Case study (6.63\%) and brainstorming (7.18\%) were variants chosen by the lowest proportion of respondents. As for teaching methods adopted by academic teachers during classes, it could be noticed that every third respondent mentioned presentations (34\%), whereas every fourth (24\%) - multimedia. Furthermore, $21 \%$ of students selected discussion, $17 \%$ - brainstorming, and $4 \%$ - case study. It is interesting to look at the structure of answers divided by the level of studies. With respect to methods employed during lectures, $42 \%$ of respondents attending first cycle studies (BSc) considered presentations as the most popular teaching method, whereas $29 \%$ of students attending second cycle studies (MSc) regarded discussion as a method willingly employed by their teachers. A similar tendency is observed as far as methods adopted during classes are concerned. The former mentioned presentations (38\%), whereas the latter indicated case study (28\%).

The above structure of answers will be supplemented by opinions expressed by the students on effective teaching methods in the field of economics. In order to present the results in a transparent way, average weights were adopted on a scale from 1 to 5 (where 1 indicates extremely low effectiveness and 5 implies extremely high effectiveness). At first the respondents were asked to select effective methods to be employed during lectures. The majority of respondents mentioned presentation (average weight 4.32), case study (average weight 4.18), discussion (average weight 2.9), working in groups (average weight 2.6) and brainstorming (average weight 2.3). Furthermore, the respondents were asked to choose the effective methods to be followed during classes. Figure 3 presents detailed results.

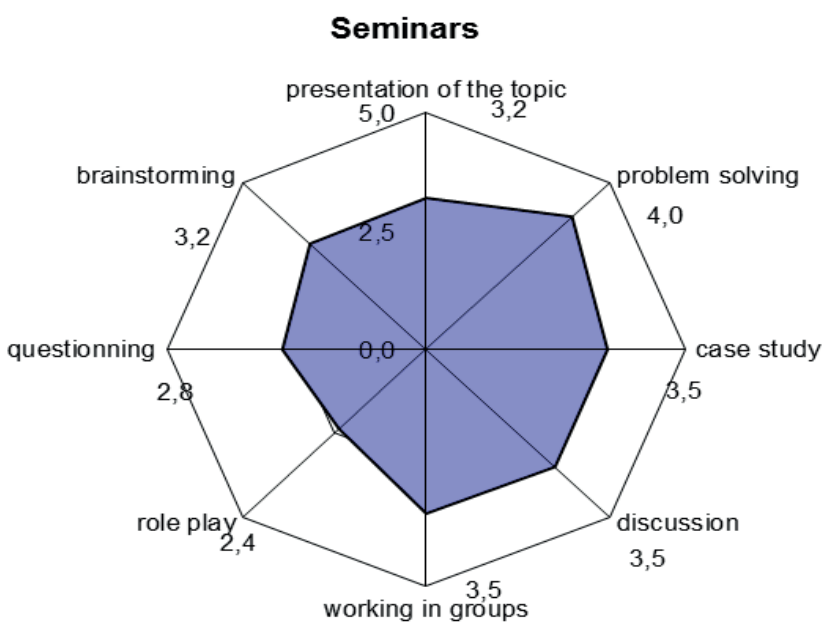

Figures 3. Effective teaching methods to be employed during classes Source: own elaboration based on the questionnaire survey 
The majority of students regarded problem solving (average weight 4.0), case study, discussion and working in groups (average weight 3.5) as effective teaching methods adopted during classes. Role play was the least popular among the students participating in the survey (average weight 2.4). Analysing the results by the fields of study, it can be stated that respondents studying management as well as finance and banking considered case study and discussion the most preferred methods to be followed during lectures and classes. On the contrary, respondents studying information science, econometrics and economics mentioned presentation. This certainly stems from differences in curricula followed in the case of particular specializations.

The survey results presented so far indicate that the respondents appreciate methods that provide them with access to practical knowledge. Nevertheless, they claim that methods employed most willingly by their teachers are the least effective. At the same time, they call for a practical dimension to classes, among other things discussing case studies more often. Therefore, for the sake of the present analysis it is of great use to get to know arguments „for" and „against” employing case studies for tertiary education in the field of economics (Tab. 1)

Table 1

Arguments for and against using case studies for educational purposes

\begin{tabular}{|l|l|}
\hline \multicolumn{1}{|c|}{ For } & \multicolumn{1}{|c|}{ Against } \\
\hline $\begin{array}{l}\text { Comes in a number of forms and requires } \\
\text { using various techniques }\end{array}$ & $\begin{array}{l}\text { Not every curriculum can be implemented } \\
\text { in the form of case study }\end{array}$ \\
\hline Makes students more active during classes & \\
\hline $\begin{array}{l}\text { Enables students to develop the ability to } \\
\text { analyse cases critically }\end{array}$ & $\begin{array}{l}\text { Teacher may lose control over students dur- } \\
\text { ing the discussion }\end{array}$ \\
\hline $\begin{array}{l}\text { Enables students to become involved in } \\
\text { teamwork and to be more precise: resolve } \\
\text { conflicts, negotiate, communicate, seek new } \\
\text { solutions }\end{array}$ & $\begin{array}{l}\text { Lack of time to discuss case study during } \\
\text { classes }\end{array}$ \\
\hline $\begin{array}{l}\text { Enables students to solve real problems with } \\
\text { the functioning of certain organizations }\end{array}$ & Unwillingness to prepare for classes \\
\hline
\end{tabular}

Source: own elaboration based on the questionnaire survey

According to the students participating in the survey, case studies allows to adopt various forms and techniques of knowledge transfer and hence can be a universal tool to be employed during classes with different groups of students. Not every group will be able to become involved in effective brainstorming. However, there are a number of alternative instruments such as teamwork, 
metaplan, simulation game, etc. thanks to which the teacher may analyse a given case study. Furthermore, according to the respondents, case studies used in teaching process encourage students to show greater interest and activity during classes. What is more important, while preparing for case study analysis, students have to gain adequate knowledge and hence become more self-reliant and responsible for the results of their work. Another argument for using case studies to teach curriculum content (mentioned by the respondents) refers to teamwork which enables students to develop number of skills, namely to present their ideas, communicate, negotiate, seek compromise. Furthermore, it should be emphasized that while solving case study students learn how to perform a critical analysis and take decisions.

It is also worth mentioning that case studies offers a chance to deal with real problems. Students highlight the fact that they are emotionally involved and identify with a given situation, which enables them to get to know their attitudes and behavioural patterns. Furthermore, one should bear in mind that students learn from one another via observation and gain knowledge thanks to learning by doing principle. The last-mentioned aspect is particularly crucial as the teacher may immediately prove the usefulness of a proposed solution.

Apart from arguments for adopting the case study method, the respondents also offered arguments against it. First of all, not every curriculum subject and content can be taught with the use of case study. Statistics and econometrics are very often quoted as examples. Nevertheless, one should keep in mind that case studies do not always have to refer absolutely to the aforementioned content. Sometimes the case under discussion may be connected indirectly with issues presented during classes. The main aim is to guide students toward proper thinking pattern. According to the respondents, another argument against is the fact that the teacher may lose control over the group during the discussion. Such a risk is always present during classes regardless of the fact if a case study is being discussed or not. In this context, the risk is the more serious, the less the teacher's ability to cooperate with the group. Needless to say, this ability depends on his/her experience and personality.

A high percentage of students suggest that the curriculum does not allow to use case study for every subject and hence during every class. The lack of time for accomplishing such tasks is another problem. This is a debatable argument since, as it has already been proven, adequate preparation of case study (the formulation of questions, aim of case study, selection of source material, or form of presentation) allows to follow curriculum content practically and not theoretically. At the same time, learning units can be adjusted to the official curriculum.

The last argument advanced by the respondents is students' unwillingness to prepare properly for discussing and thus solving case study. And again it is 
beyond any doubt that this argument is not very convincing since nowadays people are expected to improve and develop their skills and abilities. Therefore, while preparing for case studies students acquire knowledge and experience, and thereby develop their ability to think analytically and synthetically.

\section{Conclusion}

Summing up, it should be stated that the respondents consider case studies an effective tool, yet rarely used for knowledge transmission. Students are unanimous as to the fact that case study method not only enables them to acquire theoretical knowledge but - what is more important - to develop a number of skills they will certainly need in the future. The most essential skills include: critical analysis of information received, communication, presentation of one's own ideas, negotiation, teamwork. Furthermore, the respondents are inclined to believe that thanks to the method under discussion they can confront theory with practice, which only underlines the sense of education.

Nevertheless, in order to attain their goals with the use of case method, teachers need special preparation and training. They are the heart of every case study discussed during classes. They set standards and framework for solving the case. Therefore, it is strongly recommended that teachers adopted methodical suggestions presented in the article. These suggestions may certainly be subject to modification. All things considered, they are a set of rules to be followed by teachers and a foundation for solving every case study.

\section{References}

[1] Greenhalgh A.M., Case method teaching as science and art: A metaphoric approach and curricular application, "Journal of Management Education" 2007, 31(2), s. 181-194.

[2] Herreid C.F., Trigger cases versus capstone cases, "Journal of College Science Teaching" 2008, vol. 38, no 2, November/December, pp. 68-70.

[3] Iezzi D.F., A method to measure the quality on teaching evaluation of the university system: The italian case, "Social Indicators Research" 2008, 73(3), 4, pp. 59-477.

[4] Królikowska E., Najlepiej widać na przykładzie, czyli studium przypadku jako metoda nauczania, http://www.ceo.org.pl (05.08.2004).

[5] Labov W., Sociolinguistic Patterns, University of Pennsylvania Press, Pennsylvania 1972. 
[6] Martinez-Gomez M., Sierra J.M., Carot S., Jabaloyes J., Zarzo M., A multivariate method for analyzing and improving the use of student evaluation of teaching questionnaire, "A case study. Quality and Quantity" 2011, 45(6), pp. 1415-1427.

[7] Murray S., Space for thought encourages a richer vocalisation of ideas online case study teaching: Sarab murray on bow a classroom-based tutorial method is benefiting from the web, "Financial Times March" 2007.

[8] Werda W., Metoda studium przypadku $w$ dydaktyce nauk o zarzadzaniu, in: Uczelnia oparta na wiedzy. Organizacja procesu dydaktycznego oraz zarządzanie wiedza $w$ ekonomicznym szkolnictwie wyższym, red. T. Gołębiowski, M. Dąbrowski, B. Mierzejewski, Fundacja Promocji i Akredytacji Kierunków Ekonomicznych, Warszawa 2005 , pp. 217-218.

[9] Wójcik K., Sierotowicz T., Udoskonalona metoda burzy mózgów narzędziem skutecznego poszukiwania rozwiazań innowacyjnych, w: Wybrane zagadnienia funkcjonowania podmiotów gospodarczych, pod. red. R. Nowak-Lewandowskiej, Uniwersytet Szczeciński, Szczecin 2007, pp. 44-45. 